\title{
XV ICPP: VIEW FROM THE OUTSIDE AND THE INSIDE
}

\author{
XV ICPP: VISTA DESDE EL EXTERIOR Y EL INTERIOR
}

\author{
ARTUR DYDROV - REGINA PENNER \\ South Ural State University (Chelyabinsk, Russia) \\ dydrovaa@gmail.com - penner.r.v@gmail.com
}

RECIBIDO: 18 DE JULIO DE 2018

ACEPTADO: 29 DE AGOSTO DE 2018

\begin{abstract}
The article is devoted to $\mathrm{XV}^{\text {th }}$ International Conference on Philosophical Practice, which in 2018 was held in Mexico City, Mexico. The authors of the article paid special attention to those events in which they participated. Moreover, the authors raised the issue of the essence of the conference on philosophical practice, its tasks and prospects.

Keywords: philosophy, philosophical practice, conference on philosophical practice, $\mathrm{XV}^{\text {th }}$ ICPP.

Resumen: El artículo está dedicado a la XV Congreso Internacional de Práctica Filosófica, que en 2018 se llevó a cabo en la Ciudad de México, México. Los autores del artículo prestaron especial atención a aquellos eventos en los que participaron. Además, los autores plantearon la cuestión de la esencia de la conferencia sobre la práctica filosófica, sus tareas y perspectivas.
\end{abstract}

Palabras clave: filosofía, filosofía aplicada, congreso filosofía aplicada, XV ICPP.

\section{Introduction}

$\mathrm{XV}^{\text {th }}$ International Conference on Philosophical Practice $\left(\mathrm{XV}^{\text {th }}\right.$ ICPP) was held in Mexico City, Mexico, from June 25th to June 29th. For the first time ICPP was in Latin America on the basis of one of the largest American universities, la Universidad Nacional Autónoma de México (UNAM). The initiative of holding the 
conference in Mexico City was expressed in 2016 at XIV ${ }^{\text {th }}$ ICPP in Bern, Switzerland, by David Sumiacher, director of the Centro Educativo para la Creación Autónoma en Prácticas Filosóficas (CECAPFI).

Despite the fact that philosophical practice as a direction of philosophical thought has existed since the 1980s, the first international conference was held only in 1994 by the initiative of Ran Lahav and Lou Marinoff. Then the idea of conference was to unite practitioners from all over the world to exchange experiences. The purpose of the $\mathrm{XV}^{\text {th }}$ ICPP was more ambitious: "to promote the academic, educational and personal development of our assistants through the exchange and presentation of conferences, workshops, activities, panels and presentations of practical philosophers all over the world". This goal is laid not only the idea of combining philosophical practitioners and the exchange of experience (although they are present in the quote); the emphasis is on promoting the achieved results in the academic and extraacademic environments.

\section{Philosophical communities: historical retrospective}

In general, the idea of uniting philosophers is not new. Even in Dialogues by Plato Socrates expresses the idea that for the birth of truth, at least, two are needed: the "parent" of true knowledge, and the one who takes birth. In the period of Antiquity, philosophical knowledge was generated and existed on the streets; free communication between a philosopher and a non-philosopher justified the relevance of philosophical knowledge and predetermined the birth and formation of a scientific (modern rational) worldview.

Turning to the ancient period in philosophy, Pierre Hadot and Michel Foucault noted the importance of philosophical wisdom for 
non-philosophers ${ }^{1}$. During the late Roman Empire, rich patricians invited philosophers to their homes to carry out what we now call philosophical counseling.

The openness of philosophers and philosophical knowledge to the "streets" and everyday life was lost already in the Middle Ages. However, the idea of uniting philosophers is still alive today. We list only a few examples in which it is mentioned:

- A representative of early materialistic thought, the Irish philosopher John Toland at the beginning of the XVIIIth century in Manifesto of the Socratic Society calls upon fellow philosophers to raise cups for unity;

- The founder of German idealism Immanuel Kant in the later years of his life organized so-called "philosophical dinners", in which he shared his experience and knowledge with his young colleagues in an informal atmosphere;

- The ideologists and organizers of the communist movement, Karl Marx and Friedrich Engels finish their program with a phrase that has left philosophical circles: "Workers of the world, unite!" Well-known communist thinkers replaced philosopher by proletariat. In the 11th thesis on Feuerbach, Karl Marx recognizes philosophers as the only function of explaining the world; and in proletariat he puts the hope of changing this world;

- Finally, the modern American philosopher Richard McKay Rorty in 1991 formulated the idea of collective improvisation. The goal of collective improvisation is to promote interaction between different disciplines, life experiences and worldviews. Collective improvisation is rooted in the fact that thought is not only about something,

${ }^{1}$ The starting point of the systematization of the practice of the self were M. Foucault's lectures "The Hermeneutics of the Subject" and 2 work by P. Hadot "What is ancient philosophy" and "Philosophy as a way of life" 
but also a thought with someone. Collective improvisation reveals the relationship between mental generalization and interpersonal communication. This thinking in the form of co-thought combines the individual and the universal. The goal of collective improvisation can be compared with the task that Richard Rorty put forward to the thinkers of the future: "They must become universal (all purpose) intellectuals, ready to offer their ideas about anything, in the hope that these ideas will be harmoniously combined with everything else" ${ }^{2}$. Moreover, collective improvisation is not a scholarly debate, since it reveals individual and simultaneously universal approaches to the topic of general interest ${ }^{3}$.

Conventionally, collective improvisation can be called a key form of work of $\mathrm{XV}^{\text {th }}$ ICPP. The conference was built on the principles of dialogue ${ }^{4}$, brainstorming and informal communication as opposed to academic didactics and monologue.

\section{Pre and Post Conference courses}

The innovation of $\mathrm{XV}^{\text {th }}$ ICPP was Pre and Post Conference courses from leading philosophical practitioners. The organizers of the conference defined the courses as workshops to familiarize the target audience with various areas of practical philosophy. The

\footnotetext{
${ }^{2}$ RORTY, Richard: After Philosophy: End or Transformation?, The MIT Press, London, 1991; p. 56.

${ }^{3}$ EPSTEIN, Mikhail: From Knowledge to Creativity, How the Humanities Can Change the World, Center for Humanitarian Initiatives, Moscow, 2016.

${ }^{4}$ The problem of dialogue is not new to philosophical practice. For example, it was examined in the work by STAUDE, D. "The Path of Consideration. Philosophical Practice in Dialogic Life Accompaniment", in The Socratic Handbook, LIT Verlag, 2015. Pags. 35-44.
} 
duration of each course was 15 hours. The courses were held in parallel.

Pre Conference courses, June, 22-24:

- Dr. Gerd Achenbach (Germany) "Philosophical practice is the serious challenge of Philosophy";

- Dr. Ran Lahav (the USA) "Deep Philosophy";

- Dr. Walter Kohan (Brasil) "What's about living philosophy? Exercises of thought, ignorance and invention".

Post Conference courses, July, 1-3:

- Dr. Lou Marinoff (the USA) "Stoicism, Daoism, and Buddhism in Philosophical Practice";

- Dr. José Barrientos-Rastrojo (Spain) "Experience Philosophical Practice";

- Dr. Oscar Brenifier (Francia) "Philosophical Practice is an ascesis, not an exchange of opinions".

The courses synergized theory and practice. For example, Gerd Achenbach during the first two days presented the basis and principles of his philosophical counseling. As an illustration, he constantly turned to Franz' case (a young depressive intellectual with a suicidal inclination). The peculiarity of Gerd Achenbach's method is that he conducts consultations without questioning. This is fundamentally different from the method that Oscar Brenifier calls the Socratic dialogue. According to Gerd Achenbach, the philosopher's questions are taken away from the story that the guest wants to tell; the philosopher's questions create a new story that the philosopher himself wants to hear. At the same time, it is the guest, and not the philosopher, who should become the key narrative character in philosophical counseling. The task of philosopher in this case boils down to listening attentively and illustrating alternative ways of solving the questions that the guest asks. With the help of the Franz' example Gerd Achenbach showed that there 
is a difference between the real suicidal tendencies and the opinion of society that a particular person has this suicidal tendencies. Both theoretical days were held in the form of an open dialogue, when the listeners asked questions to clarify separated theses.

On the third day of the course Gerd Achenbach offered to the participants workshop. He acted as a guest, and the listeners became philosophical counselors. In a narrative form, Gerd Achenbach demonstrated a problem that has bothered him recently. Participants of the course expressed their ideas on the basis of what they heard. It turned out that working with the method "without a method" or "without questioning" is quite difficult. Another difficulty was to go beyond your own perimeter and try to enter, to understand the boundaries of the guest's problem. Throughout the workshop, Gerd Achenbach pointed out to the listeners the mistakes that they were making and suggested possible ways of avoiding them.

\section{Main forms of activity}

The conference itself began work on June 25th and consisted of 5 busy days. The main forms of activity can be identified as follows:

- Main Speeches,

- Philosophical Walks,

- Philosophical Consultations for General Public,

- Panels on Philosophical Practice,

- Theoretical \& Book Presentations,

- Round Tables,

- Philosophical Practice Workshops.

We will describe in more details the events in which we took part. But firstly, let us pay attention to the form, Philosophical Consultations for General Public. Since its design in an 
autonomous philosophical direction, philosophical practice has distanced itself from academic philosophy. The reason for this is that academic philosophy is apersonal, in extreme cases - "dead". Academic philosophy is not interested in the problems of a living person from the street; the sphere of its interests is limited by the historical and philosophical layer, the categorical apparatus and methodological resource.

$\mathrm{XV}^{\text {th }}$ ICPP has demonstrated the proximity to a person from street. Every conference day was opened with free consultations, which well-known philosophical practitioners conducted for general public. These consultations approved the idea that philosophy can begin not with a theoretical concept, but with a living problem of a non-philosopher.

\section{Main Speeches}

Due to the large number of participants (at $\mathrm{XV}^{\text {th }}$ ICPP more than 150 people from all over the world, mostly from Latin American countries, were registered) 3-6 events were organized at the same time, in parallel. In turn, Main Speech is a form of work at the conference, which takes place without parallel events.

At $\mathrm{XV}^{\text {th }}$ ICPP 3 Main Speeches were presented: by Gerd Achenbach, Ran Lahav and his companions from "Deep Philosophy Group", Lou Marinoff.

In his speech "What matters? What is important in truth? What is crucial in the end? Leading principles in philosophical practice" Gerd Achenbach dwelt on the question "Who is a philosopher?", which, in his opinion, became the key in the field of philosophical practice. Following Socrates, he outlined the principles of philosophical practice as the basis for the activities of the modern philosopher. He already answered some of his questions in his 
previous works. ${ }^{5}$ Answering a question from the audience, Gerd Achenbach confessed that he had created his own Socrates. At the same time, he asked the audience a question that remained open, does not each of us come up with his own Socrates?

The figure of philosophical practitioner was also questioned by Lou Marinoff in his lecture "Doing Good and Living Well: Awakening the Inner Philosopher". Lou Marinoff parted the concepts of "doing good" and "doing well". Moving from semantics to practice, he came to the thesis that the intentions of philosophical practitioners are "try to do good" by helping people lead "to do (i.e. to live) well".

Finally, Ran Lahav and his companions, Michele Zesse (Italy), Regina Penner (Russia), Kirill Rezvushkin (Russia), Leon de Haas (Holland), presented a new form of philosophical practice in the lecture "What is Deep Philosophy?"6. We described why we call our direction Deep Philosophy, illustrated the basic principles and exercises in the work of the direction, dwelled more on the ideas of contemplation, togetherness and transformation ${ }^{7}$. Perhaps, it was the lecture that raised the most active discussion. The problem is that many of the ideas identified in the lecture, in practice (in comparison with the above-mentioned speeches) are in an embryonic state. Principles and exercises are only groped within the work of the group members. However, the format of the lecture presupposes clear theses, not amorphous judgments. As a result, the audience did not always understand the meaning of the terms that we use, and the context of their use. So, Oscar Brenifier asked the

\footnotetext{
5 ACHENBACH, Gerd: "The basic rule of philosophical practice", in Society and Power, number 6, Moscow (Russia), 2016. Pags. 99-106.

${ }^{6}$ The main forms and procedures as well as the origin and concept idea of Deep Philosophy are described in The Deep Philosophy Book, Loyev Books, Vermont, 2018.

${ }^{7}$ This ideas are well described in Stepping out of Plato's Cave: Philosophical Counseling, Philosophical Practice and Self-Transformation by R. Lahav
} 
question of the reason for using determinant Deep instead of Contemplative or Religious. This question was answered by Leon de Haas, arguing that personally for him all 3 determinants are located in the closeness to each other.

\section{Philosophical Walks \& Philosophical Practice Workshops}

Another interesting innovation of $\mathrm{XV}^{\text {th }}$ ICPP was philosophical walks. Organizers invited participants to walk philosophically on the day of the opening of the conference. Leading walks were Walter Kohan and Oscar Brenifier. The first one concentrated his attention on inner silence and understanding of the transformation of consciousness in the process of walking. The second - on developing the ability to formulate a definition for a given concept. We took part in the Walter Kohan's walk. Before we went for a walk in the gardens of UNAM, Walter Kohan asked us to ask ourselves: what is the main thing in my life? For an hour the walk was interrupted by 2 stops. During each stop there was a question. At the first stop, we formulated the answer on the initial question. Participants began to share their answers. The answers of each sounded not atomically, divorced from many other answers; in their responses the participants resonated with each other. Each new word of another participant supplemented or extended the answer of the previous speaker. This created the effect of unison in music. Since we do not speak Spanish, this effect is enhanced by the sound of foreign speech.

During the second stop, the initial question was replaced by the question, did anything change within me during this walk? During the polylogue, we found important points: 
- A philosophical walk in the regime of a rather vigorous movement leads to a slight change in consciousness;

- In this state, consciousness focuses on the initial question;

- Along with the focus, attention is dissipated due to the constant change of the background;

- Changing the external affects the internal, corrects the formulation of the answer;

- However, in a philosophical walk it is important not even what and how it is answered on the initial question; important is how this answer is being understood;

- As a result, the walkers asked not the question What is? but the question Why does this exist for me? and What is happening to me?

- Those questions do a shift from the reflection of the external to the inner reflection.

The philosophical walk with Walter Kohan was an experiment. It seems that this experiment took place. The result was not immersion in the depths of the ego; the result is the fixation of attention on how and why the consciousness of this self changes.

A similar practical result was pursued by the Philosophical Practice Workshops.

Each international conference on philosophical practice differs from similar academic events in that it pays special attention not to theoretical disputes, but to practical work. The $\mathrm{XV}^{\text {th }}$ ICPP was no exception. The conference featured a wide range of workshops in English and Spanish. To participate in all of them (even many) was not possible, since there were 5-6 sessions at the same time. Let us dwell on a few of them, in which we took a direct part as participants or facilitators. 
Members of "Deep Philosophy Group" presented the procedures and exercises that have been developed over the past year. Workshops were held in the form of a contemplative session in the interpretation of Ran Lahav's philosophical companionship ${ }^{8}$. The workshop began with a centering exercise, which made it easier for participants to focus on the philosophical text and resonate with this text. Each member of the "Deep Philosophy Group" chose his own text, among which were excerpts from Plotinus, Paul Tillich, Karl Jaspers, Martin Buber, Clive S. Lewis and Marcus Aurelius. After concentrating on the self, the facilitator offered to immerse the self in the text with the help of several exercises, among which were interpretive reading (reading of individual sentences with the possibility of their explanation); repetitive reading (repetition of one sentence by all participants of the session); precious speaking (thinking and pronouncing one or more words as a result of resonating with the text). The final exercises of the session differed in the performance of different facilitators: from drawing a map of ideas to writing a collective poem. One thing was constant: each facilitator at the end of the session asked participants to share their feedbacks. Participants admitted that something happened during the session, but not everyone could answer the question, what happened. One of the participants experienced a strong emotional state, crying at the end of the session. A major achievement of our group was the recognition of some participants the fact that they were wary of going to the workshop. The reason for this was the Main Speech, which left more questions than answers. However, the workshop solved the questions that participants came with (what is contemplative attitude, togetherness or resonation). The position of Oscar Brenifier and his followers that philosophical practice is a work on critical thinking was widespread too. Only

8 LAHAV, Ran: Handbook of Philosophical Companionships: principles, procedures, exercises, Lovey Books, Vermont, 2016. 
Oscar facilitated 6 workshops during the conference. The scope of the workshops varied from working on thinking skills and their presentation as a public matter to practical questions about how to develop the Philosophical Practice business. Oscar Brenifier held a dialogue with the participants ${ }^{9}$. On concrete examples he demonstrated the idea that philosophical consultation like a Socratic practice is not some "intimate matter". This is the public activity of a counselor who is able to demonstrate the core of critical thinking within a consultation in public with a voluntary person, and afterwards discussed it with the observers.

Audrey Gers devoted her workshop to the conceptualization issues. Jerome Lecoq demarcated the concept of thinking between the common sense and in the philosophical consultation. Viktoria Chernenko invited the participants of her workshop to the philosophical journey of questioning; she offered participants the working on questions and examining their strength.

Socratic dialogue is a rather tough form of philosophical practice. Often it demonstrates the inability or unwillingness of a participant to accurately answer the question posed or ask the right question. This form neutralizes any form of intellectual tricks, when for a multitude of words we lose the semantic thread. Socratic dialogue in the Oscar Brenifier's version is an extremely public form of work, where public opinion is the yardstick of truth.

Another questioning in philosophical counseling is practiced by Leon de Haas. In his workshop "An exercise in phenomenological and linguistic interventions in an existential narrative", he turned into the counselee, and the participants of the workshop became his counselors. To the counselors, Leon presented his tormenting fear and invited the participants to work with this fear; not with the concept, but with concrete examples of the manifestation of fear in

\footnotetext{
${ }^{9}$ One of the main ideas of O. Brenifier's work is the art of asking questions, that was described in his articles "The art of asking questions" and "The art of Philosophical Practice: Philosophical Attitudes"
} 
the immediate past. Leon noted that in his extensive practice he tries to work not with great concepts, but with small moments of everyday life. Having worked out an understanding of himself in his daily actions, the counselee prepares to conceptualize his problem and search for its solutions.

It should also be noted that the bilingualism of the conference contributed to the multilingualism at the workshops. Only a few sessions were conducted in English only; the majority went with simultaneous translation, some - only in Spanish.

\section{Panels on Philosophical Practice}

One of the proclaimed principles of the conference was the principle of dialogue. But it is one thing to proclaim the principle, and another to realize it. A vivid example of the problematic in the implementation of the principle of dialogue was Panels on Philosophical Practice. Let us demonstrate this with a concrete example.

"Approaches \& perspectives in philosophical consultation" has become one of interesting panels, firstly, because of the stated topic; secondly, by the composition of participants (Gerd Achenbach, Lou Marinoff, Ran Lahav, Oscar Brenifier, Leon de Haas).

Well-known philosophical practitioners in a two-hour discussion could not come to a single basis. Even the way the panel members took their seats at the plenary table and how they reacted to the comments of their colleagues confirmed the audience in the idea that many of them remained at their opinion and are not ready to step onto the path of dialogue. 


\section{Round Tables, Theoretical \& Book Presentations}

Two sections of the conference were devoted to philosophical practice and education. The topic of the sections prompted clarification of important questions: about what kind of education do the participants in the sections say? What is the place of philosophical practice in education? Those conversations were about education in High Schools and Universities. It presupposes a certain organization of the pedagogical process, the use of complex techniques and methods of working with students, support for educational plans and programs, etc. During those sessions the place of philosophical practice (broader - philosophy) in education, resorting to both the theoretical principles and the specific examples, was mentioned. The presentation by Minerva Gutiérrez Sánchez was formulated by the original question: whether philosophy can be the foundation of a new concept of education? According to Minerva, this is possible if philosophy is not reduced to teaching "world-explaining" concepts. The problem, then, is to find means to "translate" philosophy from academic discipline into living, personal, intimate knowledge.

Dante Evaristo Bello Martínez saw the application of philosophy to the realities of the network and information society. In conditions of increasing information volumes, as well as an increase in the number of false messages and "empty" news, the ability to analyze (and generally understand) network information becomes a skill necessary for survival. Dante analyzes with students the messages of social networks, periodically using links to famous philosophers. In his work, philosophy is not an "application" to network information; on the contrary, it bases the analysis of network content.

In the presentation "Futurization of education: From theory to practice" Artur Dydrov briefly described the content of the strategy of futurization of education. Its meaning is reduced to the inclusion 
in the educational process topics and problems related to the future. In particular, special attention in the educational process should be given to discourses calling for a radical transformation of human nature. Philosophy in this strategy is not an instrument, but a foundation. It allows us to critically comprehend various projects of the future concerning a person. Based on the philosophical works of Jean Baudrillard, Roland Barthes, Martin Heidegger and others, as well as fragments of fantastic films, we initiate dialogues with students about ecology, technology and human nature.

Itzel Mendoza Ramírez, Paulina Abigail Flores Carzolio, Saray Barrios Aldana, María Judith Barrales López presented a new research program. The research group plans to introduce philosophy into the propaedeutic course. In addition, the topic of aesthetics, identity and virtual reality will be introduced into the learning process. The purpose of these courses is the formation of a responsible person, capable of independent decision-making and implementation of actions, the balance between the values of human and society.

Along with the section "Philosophical Practice and Education" the section "Philosophical Practice at the University" was held, where the attention of the speakers was focused on the figure of professor of philosophy and the forms of pedagogical work in the audience of universities. The presentation "Philosophical practice in university: The possibilities and limits of its application" by Regina Penner paid close attention to the image of professor of philosophy. In our opinion, professor of philosophy should meet several criteria: to use interactive forms of instruction, to listen and hear the student's words, and also to deal with philosophical sources in the most correct way; not to have "ready-made truths" and be ready to adjust opinions; have a clear idea of the goals and objectives of the learning process; not hope to achieve the expected result (idea), for which the educational activity would be carried out. I assert that compliance with the indicated criteria allows us to reduce the 
distance between professor and student. This distance arises from a student's distrust to professor's activity.

A bright event in the work of the round table was the presentation of Patricia Díaz Herrera. She talked about the teaching of philosophical courses at the University of Mexico UACM. Patricia demonstrated the effectiveness of the methods of philosophical practice. The integration of these methods and techniques into the educational process has led to an increase in the popularity of the courses taught by the Department of Philosophy. In 2016, the Department of Philosophy faced the problem of the low popularity of the courses taught and the even less popularity of attestation in the courses studied. Patricia suggested adding the course "Philosophy for Children" based on the texts of Matthew Lippman and Oscar Brenifier. Each text contained a certain problem. Participants of the course were asked to comprehend this problem and find ways to solve it. Later Patricia offered her students work with texts and asked them to "try on" the ideas of the texts for personal experience. The result was an increase in the popularity of philosophical courses among UACM students by more than $50 \%$.

Within the framework of the conference a presentation of the brief dictionary "The Language of Philosophical Practice" was held. The publication was presented to the public by professor of South Ural State University Sergey Borisov. In presentation he noted that the compilation and publication of this dictionary is a unique event for several reasons. Firstly, until now, philosophical practitioners have not attempted to codify their own rich experience and methods of work, as well as basic concepts, the bearing structures, such as philosophical counseling, companionship, philosophy for children, etc. Secondly, not all concepts and categories used by philosophical practitioners (for example, "perimeter" and "depth") are clarified. Under the direction of Sergey Borisov, Russian researchers turned to the works of Gerd Achenbach, Oscar Brenfier, Ran Lahav and other philosophical practitioners and crystallized the content of 
frequently used concepts and categories. The brief dictionary contains of two dozen terms, as well as small articles by the philosophical practitioners themselves. In the future, the dictionary will be republished and thematic dictionaries also will be published (for example, on philosophy for children).

The journal "Haser", published by the research groups "Experiencialidad" and "Filosofía Aplicada: Sujeto, sufrimiento, sociedad", was presented by philosophical practitioner from Spain Jose Barrientos. "Haser" is a scientific, expert journal dedicated to the problems of philosophical practice and education. It publishes articles by practical philosophers and professional educators interested in questions of philosophy and its connection with everyday life. At the presentation Jose Barrientos said that he was striving for a balance between theory and practice. Philosophical theory without connection with practice is expressed in a monologue. From the other point of view, practice without theory is a set of unrelated actions. "Haser" comes out annually and is indexed in various databases. In the solid baggage of publications there are articles on philosophical practice in prisons, in the system of public health, philosophy for children, philosophical walks and others.

\section{Conclusion}

Each past event lays the foundation for a new one. $\mathrm{XV}^{\text {th }}$ ICPP has formed sufficient groundwork for such events in the future. At the end of the conference, a traditional vote was taken to select a new location for the $\mathrm{XVI}^{\text {th }}$ ICPP. Viktoria Chernenko presented Russia and won. Philosophical practice is not new for Russian audience. This direction of philosophy is carefully studied over the past five 
years by a Russian professor Sergey Borisov. ${ }^{1011}$ The next conference will be held in Moscow in 2020. In preparation for this conference, we will take into account the achievements of the $\mathrm{XV}^{\text {th }}$ ICPP and try to organize a unified Philosophical Improvisation, following the testament of Richard Rorty.

The three main principles were declared in the conference in Mexico City - the principles of dialogue, brainstorming and informal communication. It is clear that the last 2 principles were realized without any apparent difficulties. In our opinion, the problem appeared in the sphere of dialogue. That is why the main question for us, as for organizers of the future XVI ${ }^{\text {th }}$ ICPP, is to find the appropriate forms of initiation dialogue between participants, including the main figures of philosophical practice.

The actualization of this issue is related to the fact that any practice is insufficient without a live dialogue of its participants. Principles of dialogue and cooperation are proclaimed today in many spheres of activity (from education to politics) as theoretical postulates. It remains to find adequate forms of their immediate implementation, which may become the basis for further implementation of Philosophical Improvisations.

\section{Acknowledgements}

The RFBR project \# 17-33-00021 "Theory and Practice of Philosophical Counseling: a Comparative Approach".

${ }^{10}$ BORISOV, Sergey: "Philosophical Practice: Therapeutic and Developing Aspects", in Philosophical traditions and Modernity, number 2, Moscow (Russia), 2015. Pags. 84-87.

${ }^{11}$ BORISOV, Sergey: "What is "Philosophical Companionship" and how to practice it", in Society and Power, number 2, Moscow (Russia), 2017. Pags. 123129. 


\section{References}

ACHENBACH, Gerd: "The basic rule of philosophical practice", in Society and Power, number 6, Moscow (Russia), 2016. Pags. 99106.

AAVV: The Deep Philosophy Book, Loyev Books, Vermont, 2018. BORISOV, Sergey: "Philosophical Practice: Therapeutic and Developing Aspects", in Philosophical traditions and Modernity, number 2, Moscow (Russia), 2015. Pags. 84-87.

BORISOV, Sergey: "What is "Philosophical Companionship" and how to practice it", in Society and Power, number 2, Moscow (Russia), 2017. Pags. 123-129.

BRENIFIER, Oscar: "The art of asking questions", available in http://cityclass.ru/brenifier_art_ask_questions (last access July 14th, 2018).

BRENIFIER, Oscar: "The art of Philosophical Practice: Philosophical Attitudes", in Society and Power, number 1, Moscow (Russia), 2018. Pags. 80-87.

EPSTEIN, Mikhail: From Knowledge to Creativity, How the Humanities Can Change the World, Center for Humanitarian Initiatives, Moscow, 2016.

FOUCAULT, Michel: Hermeneutics of the Subject, Palgrave Macmillan TM, New York, 2005.

HADOT, Pierre: What is ancient philosophy, Publishing house of humanitarian literature, Moscow, 1999.

HADOT, Pierre: Philosophy as a way of life, Kolo, Saint Petersburg, 2010.

LAHAV, Ran: Handbook of Philosophical Companionships: principles, procedures, exercises, Lovey Books, Vermont, 2016.

LAHAV, Ran: Stepping out of Plato's Cave: Philosophical Counseling, Philosophical Practice and Self-Transformation, 2 ed., Lovey Books, Vermont, 2016. 
RORTY, Richard: After Philosophy: End or Transformation?, The MIT Press, London, 1991.

STAUDE, D. "The Path of Consideration. Philosophical Practice in Dialogic Life Accompaniment", in The Socratic Handbook, LIT Verlag, 2015. Pags. 35-44. 